\title{
Making a photovoltaic cell 3rd generation through alternative methodologies
}
G. P. Gabriel'
G. A. Coelho'
J. A. de Oliveira'
L. M. P. do Espirito Santo'

\section{Abstract}

With regard to photovoltaic cells, there is, the 1 st, 2 nd and 3 rd generations. One can also cite the 3 rd generation of organic cells, which are sensitized colorant. This new energy conversion device used in a manufacturing titanium dioxide ( $\mathrm{TiO} 2)$ low cost compared with silicon that is used in conventional solar cells. The dye-sensitized cells based on the use of a colorant capable of transferring an electron in the excited state for a semiconductor, in this case, titanium dioxide, starting the process that leads to the current generation. Thus, the aim of this study was to reproduce a methodology described in most articles on the related theme, but as it got a result, there was a need to reorganize methods. The best methodology adopted was diluted titanium oxide directly to the colorant, not to cause loss of the material when immersed, thereby obtaining the operation of the cell is monitored by voltage measurement. A particularity is still being studied, about the fact that we cover the cell and it still continue to store voltage, not decreasing instantly, thus generating a doubt that it can behave like a battery and generate voltage and current. It was not possible to assess the yield percentage of the cell because the cell mounting in series for this check is required. In later studies, we intend to analyze the voltage with the change of time and the power to ascend one led lamp, thus obtaining results for graphics generation, parameters, such as the contact area that is receiving the

1 SENAI Institute of Technology in Pulp and Paper, Telêmaco Borba, Paraná, Brazil. 
sunlight, materials best they could conduct current for more cost effective, and the analysis of other types of colorants.

Keywords: photovoltaic cell; titanium dioxide; solar energy

\section{Title}

\subsection{Efficiency of cells of first, second and third generation}

With regard to photovoltaic cells, there is, the 1st, 2nd and 3rd generations, and the 1st generation based on crystalline silicon and thus a high cost of production and installation, as 2 nd generation ones, have a low cost, but the efficiency of these cells does not have a satisfactory value, the cells of 3 rd generation organic also calls include current technologies are nanocrystals, with new types of materials to improve their efficiency and reduce costs (Machado, et al. 2015, p.135).

One can also cite the $3 \mathrm{rd}$ generation of organic cells, which are sensitized colorant, also known as dyesensitized solar cell, and solar cells based on quantum dots. This new energy conversion device used in a manufacturing titanium dioxide $(\mathrm{TiO} 2)$ low cost compared with silicon that is used in conventional solar cells (Machado, et al. 2015, p.135).

\subsection{Importance of titanium oxide layer in cell photovoltaics}

The titanium oxide appears in nature in three crystalline forms Frequent: bruquita, anatase and rutile. Is a transparent semiconductor, it has a bandgap or also called energy gap is a region which has inaccessible energy states for electrons has a good photostability and is a low cost material (Agnaldo, 2006, p.78).

Most of the methods available for production of $\mathrm{TiO} 2$, produces anatase phase and rutile, or a mixture of them, and so these phases are the most studied and used in applications in photovoltaic processes. Already bruquita stage has been rarely studied, mainly due to the difficulty of obtaining it in pure form $(A g$ naldo, 2006, p.78, Kandiel, 2010).

The dye-sensitized cells based on the use of a colorant capable of transferring an electron in the excited state for a semiconductor, in this case, titanium dioxide, starting the process that leads to the current generation (Machado, et al. 2015, p.137). 
Since solar cells based on quantum dots are divided into three types: metalsemiconductor, characterized by the photovoltaic effect take place between the metal and the quantum dots; The organic cell in which the photovoltaic effect occurs at the interface between a polymer and quantum dots and, finally, the sensitized cells per quantum dots, in which the photovoltaic effect occurs at the interface between a semiconductor and quantum dots (Machado, et al. 2015, p.137).

What distinguishes these cells from other 3rd generation is precisely the use of quantum dots, which are semiconductor nanocrystals with small size enough to display quantum properties.

\subsection{Electrolyte potassium iodide}

The electrolyte in the solar cell of Grätzel type has function to capture the electron received by contraeletrodo (reduction) and send this electron to the titanium oxide electrode soaked with dye (oxidation), performing like a cyclical redox reaction

(Nogueira, 2001, p.26).

\section{Development}

\subsection{Materials and methods}

\subsubsection{Preparation of titanium oxide paste of potassium iodide solution}

The titanium oxide paste was prepared using 1.5 grams of oxide and strawberry tea $20 \mathrm{ml}$ in a porcelain crucible to obtain a homogeneous mixture with the aid of a glass rod. The solution of potassium iodide was prepared of 4 grams of iodide and $10 \mathrm{ml}$ of distilled water in a beaker (Nogueira, 2001, p.62; Machado, et al. 2015, p.137).

\section{1.2 Preparation of the negative electrolyte}

First the iron plate was cleaned with alcohol and a paper towel, and after the titanium oxide paste was spread on the surface of the plate so as to obtain a thin and homogeneous film (FIGURE 1). After drying at ambient temperature the plate was heated to a temperature of $325^{\circ} \mathrm{C}$ for 10 minutes for better adherence of the paste on the surface (Nogueira, 2001, p.62). 


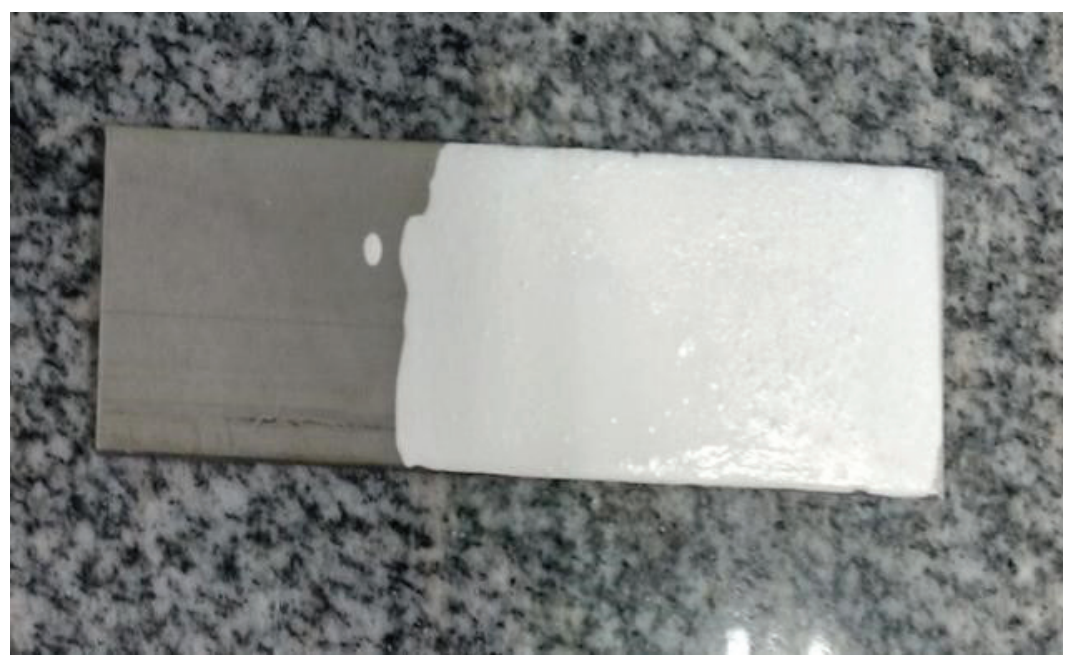

Figure 1 distribution of paste on the iron plate

Source: The author, 2016.

\subsubsection{Preparation of the electrolyte positive}

First, the glass slide was cleaned with alcohol and a paper towel, and after the surface was sanded to a better fixing of powdered graphite layer, thus the surface was darkened (Machado, et al. 2015, p.137).

\subsubsection{Mounting cell photovoltaics}

The two electrodes were attached using a paper clip. The layer of titanium oxide with the activated dye was in contact with the graphite layer. For the photovoltaic cell stay activated, a drop of potassium iodide was placed in the electrolyte. We observed the functioning of the cell, connecting the cells in multimeter and measuring the electrical current and voltage (Machado, et al. 2015, p.137).

\section{Results}

At first the aim was to play back a methodology described in most articles on the related theme, but as it did not get a result, there was a need to rearrange the methods.

The first attempt was to apply the diluted titanium oxide paste in distilled water on a glass slide, allowed to dry at ambient temperature, heat to $325^{\circ} \mathrm{C}$ blade for 10 minutes and after these procedures plunge the blade with the paste 
in strawberry tea and leave for ten minutes, with this procedure was the total detachment blade $\mathrm{TiO}_{2}$ paste, losing efficiency (Nogueira, 2001, p.62).

The second attempt was to use two glass slides by following the steps already described, but there was no fixing oxide paste on the surface.

The third attempt was wrap the glass slide with aluminum foil in an attempt to obtain conduction, but when applied to titanium oxide paste on the aluminum surface there has been no attachment, thus having a repulsive loads.

The fourth attempt was using an iron plate with the same procedures as already described, however, there was the detachment of the plate surface of the titanium oxide when dipped in natural colorant.

The fifth attempt was diluted titanium oxide directly with the colorant, not to cause loss of the material when immersed, thereby obtaining the operation of the cell, checked by measuring voltage. It was noted voltage variation, reaching high peaks as shown in Figure 2. A particularity is still being studied, about the fact to cover the cell and it still continue to store voltage, not decreasing instantly, thus generating a doubt that it can behave like a battery and generate voltage and current.

Various forms of attempts have been performed with a primary focus on the best analysis, if looked also the fact that it is possible to remove the glass with the graphite layer, placing the substance directly to the layer of titanium oxide and adding the iodide potassium, the result was achieved successfully because there was the presence of voltage in the system in an environment with artificial light and sunlight.
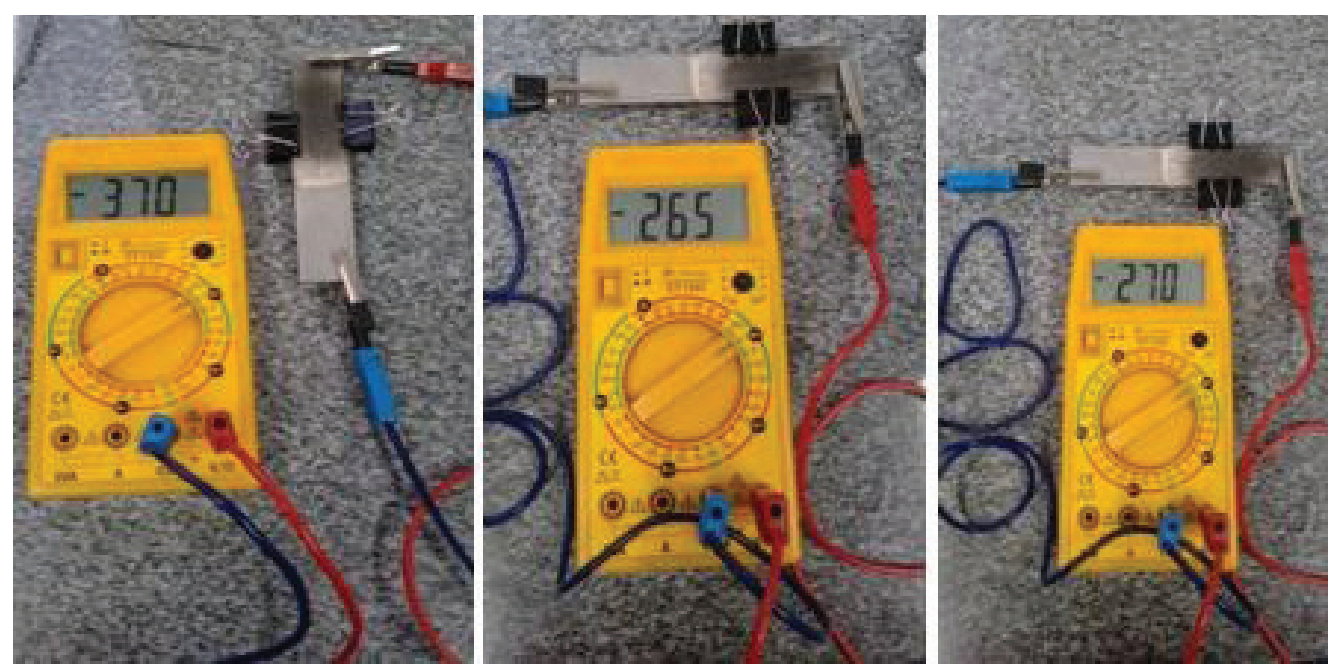

Figure 2 Multimeter measuring the voltage

Source: The author, 2016. 


\section{Conclusion}

It was not possible to assess the yield percentage of the cell because the cell mounting in series for this check is required. In later studies, we intend to analyze the voltage with the change of time and the power to ascend one led lamp, thus obtaining results for graphics generation, parameters, such as the contact area that is receiving the sunlight, materials best they could conduct current for more cost effective.

The colorant used must be assessed in relation to their awareness and should be tested other types, but directly from fruit or vegetables for a better analysis parameter since this work was used a colorant in the form of tea.

Finally, the potassium iodide was reacted with titanium oxide and graphite, causing a oxirredução may be considered other forms of iodide to better response as well as the concentration must also be evaluated.

\section{References}

AGNALDO, J. S.; BASTOS, J. B. V.; CRESSONI, J. C.; VISWANATHAN, G. M.; Células solares de $\mathrm{TiO} 2$ sensibilizado por corante. Revista Brasileira de Ensino de Física. 28, 77-84, 2006.

KANDIEL, T. A.; Tailored Titanium Dioxide Nanomaterials: Anatase Nanoparticles and Brookite Nanorods as Highly Active Photocatalysts. Chemistry of Materials.22, 2050- 2060, 2010.

MACHADO, C. T.; MIRANDA, F. S.; Energia Solar Fotovoltaica: Uma Breve Revisão. Revista. Virtual Química. 7, 126-143, 2015.

NOGUEIRA, A. F.; Células Solares de "Gratzel” com eletrólito polimérico. Tese de Doutorado, Universidade Estadual de Campinas, 2001. 